\title{
Effects of dietary $\beta$-mannanase supplementation on the additivity of true metabolizable energy values for broiler diets
}

\author{
Byung Bo Lee ${ }^{1, a}$, Tae Sung Yang ${ }^{1, a}$, Doyun Goo ${ }^{1}$, Hyeon Seok Choi ${ }^{1}$, Franco Martinez Pitargue ${ }^{1}$, \\ Hyunjung Jung ${ }^{2}$, and Dong Yong Kil'*
}

\section{* Corresponding Author: Dong Yong Kil Tel: +82-31-670-3028, Fax: +82-31-676-2196 E-mail: dongyong@cau.ac.kr \\ 'Department of Animal Science and Technology, Chung-Ang University, Anseong 17546, Korea ${ }^{2}$ Animal Nutrition and Physiology Team, National Institute of Animal Science, Rural Development Administration, Wanju 54875, Korea \\ a These authors contributed equally to this work. \\ ORCID \\ Dong Yong Kil \\ https://orcid.org/0000-0002-9297-849X}

Submitted Oct 30, 2017; Revised Dec 17, 2017; Accepted Jan 24, 2018
Objective: This experiment was conducted to determine the effects of dietary $\beta$-mannanase on the additivity of true metabolizable energy (TME) and nitrogen-corrected true metabolizable energy $\left(\mathrm{TME}_{\mathrm{n}}\right)$ for broiler diets.

Methods: A total of 144 21-day-old broilers were randomly allotted to 12 dietary treatments with 6 replicates. Five treatments consisted of 5 ingredients of corn, wheat, soybean meal, corn distillers dried grains with solubles, or corn gluten meal. One mixed diet containing $200 \mathrm{~g} / \mathrm{kg}$ of those 5 ingredients also was prepared. Additional 6 treatments were prepared by mixing $0.5 \mathrm{~g} / \mathrm{kg}$ dietary $\beta$-mannanase with those 5 ingredients and the mixed diet. Based on a precision-fed chicken assay, TME and $\mathrm{TME}_{\mathrm{n}}$ values for 5 ingredients and the mixed diet as affected by dietary $\beta$-mannanase were determined.

Results: Results indicated that when $\beta$-mannanase was not added to the diet, measured $\mathrm{TME}$ and $\mathrm{TME}_{\mathrm{n}}$ values for the diet did not differ from the predicted values for the diet, which validated the additivity. However, for the diet containing $\beta$-mannanase, measured $\mathrm{TME}_{\mathrm{n}}$ value was greater $(\mathrm{p}<0.05)$ than predicted $\mathrm{TME}_{\mathrm{n}}$ value, indicating that the additivity was not validated.

Conclusion: In conclusion, the additivity of energy values for the mixed diet may not be guaranteed if the diet contains $\beta$-mannanase.

Keywords: Additivity of Energy Values; Broiler Chicken; Dietary $\beta$-mannanase; True Metabolizable Energy

\section{INTRODUCTION}

When animal diets are formulated, there is a basic assumption that the total supply of available energy and nutrients in the mixed diet is equal to the sum of available energy and nutrients provided by each ingredient, which is often referred to the additivity [1]. Based on this fundamental assumption, animal nutritionists formulate a mixed diet with various sources and inclusion levels of feed ingredients. Thus, the additivity of energy and nutrient utilization is very important in diet formulation. The additivity for amino acid and phosphorus utilization in diet formulation has been validated for pigs [2,3] and poultry [4,5]. However, the information regarding the additivity of available energy in poultry diets is limited although energy ingredients are included at the highest levels and are the most expensive components in the diets [6].

The application of dietary enzymes targeting non-starch polysaccharides (NSPs) in diets is currently of major interest in the poultry industry because of their ability to improve energy and nutrient utilization in diets via both increased utilization of NSPs and decreased anti-nutritional effects of NSPs [7]. Dietary $\beta$-mannanase is an exogenous enzyme that hydrolyzes $\beta$-mannan, which accounts for $15 \%$ to $37 \%$ of the total concentration of NSPs in 
poultry diets [8]. There has been mounting evidence that dietary $\beta$-mannanase can increase energy and nutrient utilization, and thus, could decrease energy and nutrient supply in poultry diets [9-11]. However, the assumption that available energy values for ingredients are additive if dietary $\beta$-mannanase is added to the poultry diet has not been validated.

Therefore, the objective of the current experiment was to determine the effects of dietary $\beta$-mannanase supplementation on the additivity of true metabolizable energy values for the mixed diet fed to broiler chickens.

\section{MATERIALS AND METHODS}

The protocol for this experiment was reviewed and approved by the Institutional Animal Care and Use Committee at ChungAng University.

\section{Birds, diets, and experimental design}

A total of 144 21-day-old Ross 308 broiler chickens (initial body weight $=0.95 \pm 0.01 \mathrm{~kg}$ ) were randomly allotted to 1 of 12 dietary treatments with 6 replicates consisting of 2 birds per replicate. Two birds ( 1 male and 1 female) were raised together in a metabolic cage $(35.2 \mathrm{~cm} \times 45.0 \mathrm{~cm} \times 55.3 \mathrm{~cm}=$ width $\times$ length $\times$ height). Room temperature was set at $23^{\circ} \mathrm{C}$ and the light was provided for $24 \mathrm{~h}$ during the experiment. Five treatments consisted of 5 ingredients of corn, wheat, soybean meal (SBM), corn distillers dried grains with solubles (DDGS), or corn gluten meal (CGM), which are the common ingredients for poultry diets. Those are prepared in a ground form. One mixed diet containing $200 \mathrm{~g} / \mathrm{kg}$ of those 5 ingredients also was prepared. Analyzed nutrient and energy content in the 5 ingredients and the mixed diet were presented in Table 1. Additional 6 treatments were prepared by mixing $0.5 \mathrm{~g} / \mathrm{kg} \beta$-mannanase (CTCZYME; declared activity of 800,000 unit $/ \mathrm{kg}$, CTCbio, Inc., Seoul, Korea) with those 5 ingredients and the mixed diet.

A precision-fed chicken assay was conducted based on the method demonstrated by Kim et al [12]. In brief, broiler chicks were obtained at 1 day of age and were fed a commercial diet until 20 day of age. All birds were provided with diets and

Table 1. Analyzed nutrient and energy contents of ingredients and a mixed diet ( $\mathrm{g} / \mathrm{kg}$, as-fed basis)

\begin{tabular}{lcccccc}
\hline Items & Corn & Wheat & SBM & DDGS & CGM & Mixed diet ${ }^{1)}$ \\
\hline Dry matter & 913.0 & 910.0 & 923.0 & 924.0 & 960.0 & 935.0 \\
GE (MJ/kg) & 16.6 & 16.3 & 17.9 & 19.2 & 23.1 & 18.6 \\
Crude protein & 70.0 & 97.0 & 435.0 & 275.0 & 617.0 & 309.0 \\
Crude ash & 11.0 & 15.0 & 65.0 & 46.0 & 11.0 & 30.0 \\
Ether extract & 52.0 & 19.0 & 19.0 & 107.0 & 69.0 & 47.0 \\
\hline
\end{tabular}

SBM, soybean meal; DDGS, corn distillers dried grains with solubles; CGM, corn gluten meal; $G E$, gross energy.

1) The mixed diet $(1,000 \mathrm{~g} / \mathrm{kg})$ contained $200 \mathrm{~g} / \mathrm{kg}$ of 5 individual ingredients including corn, wheat, SBM, DDGS, and CGM. water ad libitum before the start of the precision-feeding. At the start of the experiment ( 21 day of age), all birds were fasted for 12 hours to empty their gastrointestinal tracts. After the 12-hour fasting, broiler chickens were fed $15 \mathrm{~g}$ of each ingredient or the mixed diet by a crop intubation. All excreta samples were collected continuously for 48 hours. Additional 16 birds were used to estimate endogenous losses of energy and nitrogen (N). Those birds also were fasted for 12 hours, and afterwards excreta were collected for 48 hours, which was similar to birds assigned to dietary treatments.

Collected excreta samples were dried and finely ground for the subsequent analysis. The samples for 5 ingredients and the mixed diet were analyzed for dry matter [13], ether extract [13], and crude ash [13]. The samples for 5 ingredients, the mixed diet and all excreta also were analyzed for $\mathrm{N}$ [13] and gross energy (GE) using bomb calorimetry (Model 6400; Parr Instruments Co., Moline, IL, USA) with benzoic acid used as the standard for calibration.

\section{Calculations and statistical analysis}

The values for true metabolizable energy (TME) and N-corrected true metabolizable energy $\left(\mathrm{TME}_{\mathrm{n}}\right)$ of the ingredients and diets were calculated as followed [14]:

$$
\begin{aligned}
& \operatorname{TME}(\mathrm{MJ} / \mathrm{kg})=\frac{(\mathrm{GEi}-\mathrm{GEo}+\mathrm{GEe})}{\text { feed intake }} \\
& \operatorname{TME}_{\mathrm{n}}(\mathrm{MJ} / \mathrm{kg}) \\
& =\frac{\{\mathrm{GEi}-[\mathrm{GEo}+(\mathrm{Ni}-\mathrm{No}) \times 0.034]+[\mathrm{GEe}+(\mathrm{Ni}-\mathrm{No}) \times 0.034]\}}{\text { feed intake }}
\end{aligned}
$$

Where GEi represents the GE intake; GEo represents the GE output; Ni-No represents the gram N balance; GEe represents endogenous loss of energy; $0.034(\mathrm{MJ} / \mathrm{g})$ equals the $\mathrm{N}$ retained value [15].

The additivity of TME and $\mathrm{TME}_{\mathrm{n}}$ values for the mixed diet was determined based on similarity between measured energy values for the diet and predicted energy values for the diet, which was calculated from the measured energy value for each ingredient [2].

All data were analyzed using the MIXED procedure of SAS (SAS Institute Inc., Cary, NC, USA). The replicate was considered as the experimental unit. Outlier data were identified according to the UNIVARIATE procedure of SAS, but no outliers were detected. The model included the main effects of dietary $\beta$-mannanase supplementation. The LSMEANS procedure was used to calculate mean values. For the determination of additivity, the differences in the values for TME and $\mathrm{TME}_{\mathrm{n}}$ between measured and predicted values were estimated using the LSMEANS option in the MIXED procedure. The confidence intervals for the differences were estimated with an $\alpha$-level of 0.05 . If the confidence interval for the dif- 
ference included zero, the difference between measured and predicted values was not considered significant, indicating that the assumption of additivity was warranted [2]. Significance for statistical tests was set at $\mathrm{p}<0.05$.

\section{RESULTS AND DISCUSSION}

\section{TME and $\mathrm{TME}_{\mathrm{n}}$}

The analyzed concentrations of total nutrients and GE in each ingredient (Table 1) were comparable and were within the range of previously reported values [16-18]. In addition, the analyzed concentrations of total nutrients and GE in the mixed diet containing $200 \mathrm{~g} / \mathrm{kg}$ of 5 ingredients were close to those calculated from total nutrients and GE in each ingredient, confirming that total nutrients and GE in the mixed diet were additive.

The measured $\mathrm{TME}_{\mathrm{n}}$ values for corn and wheat when no $\beta$-mannanase enzyme was added (Table 2 ) were similar to the values for corn (14.5 and $14.6 \mathrm{MJ} / \mathrm{kg}$ ) and wheat (13.3 and 13.1 $\mathrm{MJ} / \mathrm{kg}$ ) reported by NRC [16] and Rostagno et al [17], respectively. This result indicated that our experimental procedure of a precision-fed chicken assay was valid for measuring $\mathrm{TME}_{\mathrm{n}}$ values for ingredients fed to broiler chickens. However, the measured $\mathrm{TME}_{\mathrm{n}}$ values for SBM and CGM were greater than the values for SBM (10.4 and 10.8 MJ/kg) and CGM (15.9 and $16.2 \mathrm{MJ} / \mathrm{kg}$ ) reported by NRC [16] and Rostagno et al [17], respectively. In addition, the measured $\mathrm{TME}_{\mathrm{n}}$ value for DDGS was less than the value $(13.0 \mathrm{MJ} / \mathrm{kg})$ reported by NRC [16], but similar to the value $(11.8 \mathrm{MJ} / \mathrm{kg})$ reported by Batal and Dale [19]. Different origin and processing of those ingredients including SBM, CGM, and DDGS, and different experimental conditions among experiments may be the primary reason for this variation.

The addition of $0.5 \mathrm{~g} / \mathrm{kg} \beta$-mannanase had no effects on $\mathrm{TME}$ and $\mathrm{TME}_{\mathrm{n}}$ values for all 5 ingredients (Table 2). Likewise, TME and $\mathrm{TME}_{\mathrm{n}}$ values for the mixed diet containing $200 \mathrm{~g} / \mathrm{kg}$ of those ingredients were not affected by dietary $\beta$-mannanase. These results may indicate that dietary $\beta$-mannanase has little effects on true energy metabolizability in ingredients and diets fed to broiler chickens. However, previous experiments reported that dietary $\beta$-mannanase increased apparent metabolizability of nutrients [9,11] and energy [20] in diets fed to broiler chickens. The reason for this discrepancy is not clear, but it may be related to the effect of dietary $\beta$-mannanase on endogenous energy losses because we measured true metabolizable energy but previous experiments measured apparent metabolizable energy as affected by dietary $\beta$-mannanase. However, no data regarding apparent and true energy metabolizability as affected by dietary supplementation of enzymes have been available in poultry.

\section{Additivity validation}

For the diet containing no $\beta$-mannanase, measured TME and $\mathrm{TME}_{\mathrm{n}}$ values for the diet were very close to predicted TME and

Table 2. Effects of dietary $\beta$-mannanase supplementation on the values for true metabolizable energy (TME) and nitrogen-corrected true metabolizable energy (TME $)$ of 5 ingredients and the mixed diet fed to broiler chickens ${ }^{11}$

\begin{tabular}{|c|c|c|c|c|c|c|c|c|}
\hline \multirow{3}{*}{ Items } & \multicolumn{4}{|c|}{ TME (MJ/kg) } & \multicolumn{4}{|c|}{$\mathrm{TME}_{\mathrm{n}}(\mathrm{MJ} / \mathrm{kg})$} \\
\hline & \multicolumn{2}{|c|}{$\beta$-mannanase $(\mathrm{g} / \mathrm{kg})$} & \multirow{2}{*}{ SEM } & \multirow{2}{*}{$p$-value } & \multicolumn{2}{|c|}{$\beta$-mannanase $(\mathrm{g} / \mathrm{kg})$} & \multirow{2}{*}{ SEM } & \multirow{2}{*}{ p-value } \\
\hline & 0 & 0.5 & & & 0 & 0.5 & & \\
\hline Corn & 14.7 & 14.7 & 0.36 & 0.96 & 14.6 & 14.6 & 0.34 & 0.95 \\
\hline Wheat & 14.0 & 13.4 & 0.31 & 0.23 & 13.8 & 13.2 & 0.22 & 0.11 \\
\hline SBM & 12.7 & 12.4 & 0.62 & 0.77 & 11.8 & 11.9 & 0.40 & 0.92 \\
\hline DDGS & 12.5 & 12.5 & 0.46 & 0.94 & 11.4 & 11.2 & 0.42 & 0.70 \\
\hline CGM & 19.8 & 19.8 & 0.56 & 1.00 & 18.0 & 18.1 & 0.30 & 0.80 \\
\hline Mixed diet ${ }^{2)}$ & 14.8 & 15.3 & 0.33 & 0.34 & 14.0 & 14.4 & 0.22 & 0.25 \\
\hline
\end{tabular}

SEM, standard error of means; SBM, soybean meal; DDGS, corn distillers dried grains with solubles; CGM, corn gluten meal.

1) Data are least square means of 6 observations per treatment.

2) The mixed diet containing $200 \mathrm{~g} / \mathrm{kg}$ corn, $200 \mathrm{~g} / \mathrm{kg}$ wheat, $200 \mathrm{~g} / \mathrm{kg}$ SBM, $200 \mathrm{~g} / \mathrm{kg}$ DDGS, and $200 \mathrm{~g} / \mathrm{kg}$ CGM.

Table 3. Measured and predicted values for true metabolizable energy (TME) and nitrogen-corrected true metabolizable energy (TME $)_{n}$ in a mixed diet ${ }^{1)}$

\begin{tabular}{|c|c|c|c|c|c|c|c|c|}
\hline \multirow{2}{*}{ Items } & \multicolumn{4}{|c|}{ No $\beta$-mannanase } & \multicolumn{4}{|c|}{$0.5 \mathrm{~g} / \mathrm{kg} \beta$-mannanase addition } \\
\hline & Measured & Predicted & Difference & $\mathrm{SE}^{2)}$ & Measured & Predicted & Difference & $\mathrm{SE}^{2)}$ \\
\hline TME (MJ/kg) & 14.8 & 14.7 & 0.1 & 0.32 & 15.3 & 14.6 & 0.7 & 0.34 \\
\hline $\mathrm{TME}_{\mathrm{n}}(\mathrm{MJ} / \mathrm{kg})$ & 14.0 & 13.9 & 0.1 & 0.24 & 14.4 & 13.8 & $0.6^{3)}$ & 0.20 \\
\hline
\end{tabular}

${ }^{1)}$ Data are least square means of 6 observations per treatment. Measured values for a mixed diet were directly determined (Table 2), whereas predicted values were calculated from measured values for 5 ingredients (Table 2) with an additive assumption.

${ }^{2)}$ Standard error of the difference between measured and predicted values.

${ }^{3)}$ Measured and predicted values differ at $p<0.05$. 
$\mathrm{TME}_{\mathrm{n}}$ values, showing very high additivity (Table 3 ). However, when $\beta$-mannanase was added to the diet, measured TME and $\mathrm{TME}_{\mathrm{n}}$ values for the diet were greater by $4.6 \%$ and $4.2 \%$, respectively, than predicted TME and $\mathrm{TME}_{\mathrm{n}}$ values; however, the difference was significant $(\mathrm{p}<0.05)$ only for the $\mathrm{TME}_{\mathrm{n}}$ values. This result indicated that the additivity of $\mathrm{TME}_{\mathrm{n}}$ values for the diet was not warranted if the diet contains $\beta$-mannanase. It may be speculated that energy values from each ingredient may not additive in mixed diets if dietary enzyme is included because possible interactions exist among energy utilization in ingredients by dietary enzymes. However, the clear reason why values were additive for TME, but not for $\mathrm{TME}_{\mathrm{n}}$ of diets is difficult to explain. One possible reason is that the N-correction for TME values to determine $\mathrm{TME}_{\mathrm{n}}$ values decreased the variation (i.e., SEM) of the data, and therefore, increased the probability of detecting the significance. A similar result was observed in our previous experiment reporting that dietary multi-enzymes increased both TME and $\mathrm{TME}_{\mathrm{n}}$ values for diets fed to broiler chickens, but significance was observed only for $\mathrm{TME}_{\mathrm{n}}$ values mainly due to lowered SEM values [21].

In conclusion, addition of dietary $\beta$-mannanase to ingredients and mixed diets has no effects on TME and $\mathrm{TME}_{\mathrm{n}}$ values for the ingredients and mixed diets. For a diet containing no $\beta$-mannanase, there is a clear additivity of energy values for the mixed diet. However, when $\beta$-mannanase is added to the diet, the additivity of energy values for the diet may not be warranted.

\section{CONFLICT OF INTEREST}

We certify that there is no conflict of interest with any financial organization regarding the material discussed in the manuscript.

\section{ACKNOWLEDGMENTS}

This research was carried out with the support of the Cooperative Research Program for Agriculture Science and Technology Development (ID: PJ01252804), Rural Development Administration, Republic of Korea. This research also was supported by the Chung-Ang University Research Scholarship Grants in 2018.

\section{REFERENCES}

1. Furuya S, Kaji Y. Additivity of the apparent and true ileal digestible amino acid supply in barley, maize, wheat or soyabean meal based diets for growing pigs. Anim Feed Sci Technol 1991;32:321-31.

2. Stein HH, Pedersen C, Wirt AR, Bohlke RA. Additivity of values for apparent and standardized ileal digestibility of amino acids in mixed diets fed to growing pigs. J Anim Sci 2005;83:
2387-95.

3. Xue PC, Ragland D, Adeola O. Determination of additivity of apparent and standardized ileal digestibility of amino acids in diets containing multiple protein sources fed to growing pigs. J Anim Sci 2014;92:3937-44.

4. Angkanaporn K, Ravindran V, Bryden WL. Additivity of apparent and true ileal amino acid digestibilities in soybean meal, sunflower meal, and meat and bone meal for broilers. Poult Sci 1996;75:1098-103.

5. Kong C, Adeola O. Additivity of amino acid digestibility in corn and soybean meal for broiler chickens and white pekin ducks. Poult Sci 2013;92:2381-8.

6. Kil DY, Kim BG, Stein HH. Feed energy evaluation for growing pigs. Asian-Australas J Anim Sci 2013;26:1205-17.

7. Masey O’Neill HV, Smith JA, Bedford MR. Multicarbohydrase enzymes for non-ruminants. Asian-Australas J Anim Sci 2014; 27:290-301.

8. CVB. Veevoedertabel (feeding value of feed ingredients). Lelystad, The Netherlands: Central Veevoeder Bureau; 1998.

9. Cho JH, Kim IH. Effects of beta-mannanase supplementation in combination with low and high energy dense diets for growing and finishing broilers. Livest Sci 2013;154:137-43.

10. Kim MC, Kim JH, Pitargue FM, et al. Effect of dietary $\beta$-mannanase on productive performance, egg quality, and utilization of dietary energy and nutrients in aged laying hens raised under hot climatic conditions. Asian-Australas J Anim Sci 2017;30:1450-5.

11. Kong C, Lee JH, Adeola O. Supplementation of $\beta$-mannanase to starter and grower diets for broilers. Can J Anim Sci 2011; 91:389-97.

12. Kim EJ, Utterback PL, Parsons CM. Development of a precision-fed ileal amino acid digestibility assay using 3-week-old broiler chicks. Poult Sci 2011;90:396-401.

13. AOAC International. Official methods of analysis. 16th ed. Arlington, VA, USA: Association of Official Analytical Chemists; 1995.

14. Wolynetz MS, Sibbald IR. Relationships between apparent and true metabolizable energy and the effects of a nitrogen correction. Poult Sci 1984;63:1386-99.

15. Hill FW, Anderson DL. Comparison of metabolizable energy and productive energy determinations with growing chicks. J Nutr 1958;64:587-603.

16. Committee on Nutrients Requirements of Poultry, National Research Council. Nutrient requirements of poultry. 9th ed. Washington, DC, USA: The National Academies Press; 1994.

17. Rostagno HS, Becker BG, Zootecnia UFdVDd. Brazilian tables for poultry and swine: Composition of feedstuffs and nutritional requirements. 3rd ed: Viçosa, MG, Brazil: Universidade Federal de Viçosa, Departamento de Zootecnia; 2011.

18. Committee on Nutrients Requirements of Swine, National Research Council. Nutrient requirements of swine. 11th ed. Washington, DC, USA: The National Academies Press; 2012. 
19. Batal AB, Dale NM. True metabolizable energy and amino acid digestibility of distillers dried grains with solubles. J Appl Poult Res 2006;15:89-93.

20. Ferreira HC, Jr., Hannas MI, Albino LF, et al. Effect of the addition of beta-mannanase on the performance, metabolizable energy, amino acid digestibility coefficients, and immune functions of broilers fed different nutritional levels. Poult Sci
2016;95:1848-57.

21.Kim JW, Shin HS, Kil DY. Effects of total collection method and dietary enzymes supplementation on the energy utilization and metabolizable energy values of diets fed to broiler chickens. Europ Poult Sci 2016; http://dx.doi.org/10.1399/ eps.2016.126 